\title{
WATER DISTRIBUTION IN NORMAL SUBJECTS AND IN PATIENTS WITH LAËNNEC'S CIRRHOSIS
}

\author{
BY HELENA GILDER, S. FRANK REDO, DAVID BARR, AND CHARLES \\ GARDNER CHILD, III
}

(From the Department of Surgery, The New York Hospital-Cornell Medical Center, New York, $N . Y$.)

(Submitted for publication September 1, 1953; accepted December 30, 1953)

The development of ascites and edema in patients with Laënnec's cirrhosis is believed by some to be due to a deranged hormonal balance which results in salt and water retention (1-5). The present investigation analyzes the components of total body water in 22 control subjects and $15 \mathrm{pa}-$ tients with Laënnec's cirrhosis to ascertain the distribution of the retained salt and water.

\section{METHODS}

The control subjects were patients on the surgical wards for minor procedures which influence water and electrolyte balance minimally. The patients with cirrhosis were admitted for therapeutic operative procedures, observation, or treatment of ascites.

Plasma volume was measured by the method of Gibson, Evelyn, and Gregerson using the dye, T-1824, (Evans Blue) $(6,7)$. Blood volume was calculated from the value of the plasma volume or T-1824 space and the hematocrit. Radioactive sodium was utilized to measure the extracellular space plus the additional space into which sodium presumably passes. Total body water was determined by the dilution of injected deuterium oxide.

The patients were in a basal state at the time of the study. After taking a pre-injection blood sample the needle was left in the vein and to it was attached a threeway stopcock, to one arm of which was fastened a syringe containing saline. To the other arm of the stopcock was attached a $50 \mathrm{ml}$. burette equipped with rubber tubing and adapter which was filled to the adapter with a saline solution containing approximately 70 microcuries of radioactive sodium ${ }^{1}$ and $3 \mathrm{ml}$. of 0.45 per cent dye T-1824 in each $10 \mathrm{ml}$. The stopcock was opened and about $10 \mathrm{ml}$. of this solution was allowed to enter by gravity. The exact quantity injected was measured on the burette and the material left in the stopcock and needle washed into the vein with the saline in the syringe. The burette and adapter were then removed, and a weighed $50-\mathrm{ml}$. syringe con-

1 Radioactive sodium received from Brookhaven $\mathrm{Na}$ tional Laboratories as the carbonate $\left(\mathrm{Na}_{2}{ }^{2} \mathrm{CO}_{8}\right)$ was first prepared by diluting in sterile saline, neutralizing with the calculated amount of $6 \mathrm{~N}$ hydrochloric acid, sterilizing by filtration through an ultrafine sintered glass filter, and boiling on a hot plate for 15 minutes. The 70 microcuries given represents a dosage of about 0.1 roentgen, one-third the accepted tolerance level of 0.3 roentgen per week. taining the deuterium oxide-saline solution ${ }^{2}$ was attached. The stopcock was again opened and the deuterium oxide was injected under slight pressure in a period of about 2 minutes. The deuterium oxide remaining in stopcock and needle was washed into the vein in a manner similar to that of the first solution. The difference between the weights of the full and the empty syringe was taken as the weight of the deuterium oxide solution injected.

Ten minutes after the injection of the dye T-1824 and the radioactive sodium, a blood sample was taken for determination of plasma volume. Three hours after the injection a blood sample was taken for measuring sodium and deuterium oxide space. Twenty-four hours after the injection another blood sample was taken for the determination of the 24-hour sodium space and total exchangeable sodium. Radioactive sodium was measured in 24hour urine samples to correct for loss of radioactive sodium in the calculation of total exchangeable sodium. It was unnecessary to correct for urinary excretion of $\mathrm{Na}^{24}$ or deuterium oxide at the three-hour period because the amount excreted up to this time was negligible.

For the purpose of the present work the term "sodium space" is used to signify the volume of fluid in which radioactive sodium has been diluted at any particular time after injection. It is not intended to suggest that the sodium space is an anatomical entity. It signifies that radioactive sodium is diluted in a certain fluid volume at a certain time. The three-hour sodium space has been tentatively taken as the point at which equilibrium of radioactive sodium throughout the sodium containing body fluids has occurred.

Blood samples were heparinized except those taken for serum protein determinations. They were centrifuged within 10 minutes of sampling and the plasma immediately removed from the cells. Radioactivity of one $\mathrm{ml}$. of plasma was determined on one inch planchets at an endwindow counter. Radioactivity of a sample of the material injected suitably diluted was measured at the same time. The sodium space was calculated after correcting the counts per minute for background. The total exchangeable sodium was determined and calculated according to the method of Forbes and Perley (8).

2 The deuterium oxide was received in $100 \mathrm{Gm}$. ampules from Stuart Oxygen Co. Solid sodium chloride was added to make a concentration of $0.85 \mathrm{Gm}$. of sodium chloride in $100 \mathrm{ml}$. deuterium oxide. The solution was sterilized by passage through an ultrafine sintered glass filter. 
The deuterium oxide level of the three-hour plasma sample was determined by the vacuum distillation procedure and falling drop method $(9,10)$. Protein determinations were done by the microkjeldahl method of Hiller, Plazin, and Van Slyke (11) using the Howe sodium sulfate fractionation procedure to separate albumin from globulin (12). Plasma sodium levels were determined on a Barclay flame photometer utilizing the internal standard technique.

\section{RESULTS}

Figure 1 illustrates the changes in sodium space in two typical control patients (No. 1 and No. 2) and two patients with cirrhosis (No. 3 and No. 4) when plasma was drawn 40 minutes, $2,3,6,9,12$, and 24 hours after injection. The patients were in basal conditions until after the three-hour sample had been taken after which they followed the usual hospital routine of meals and activity. In control patients No. 1 and No. 2 and in patient No. 3 who had cirrhosis without ascites, the sodium space rose rapidly in the first three hours. During the rest of the day the sodium space varied erratically, at times rising above and at other times falling below

\section{SODIUM SPACE AT INTERVALS FOR 24 HOURS FOLLOWING INJECTION OF RADIOACTIVE SODIUM}

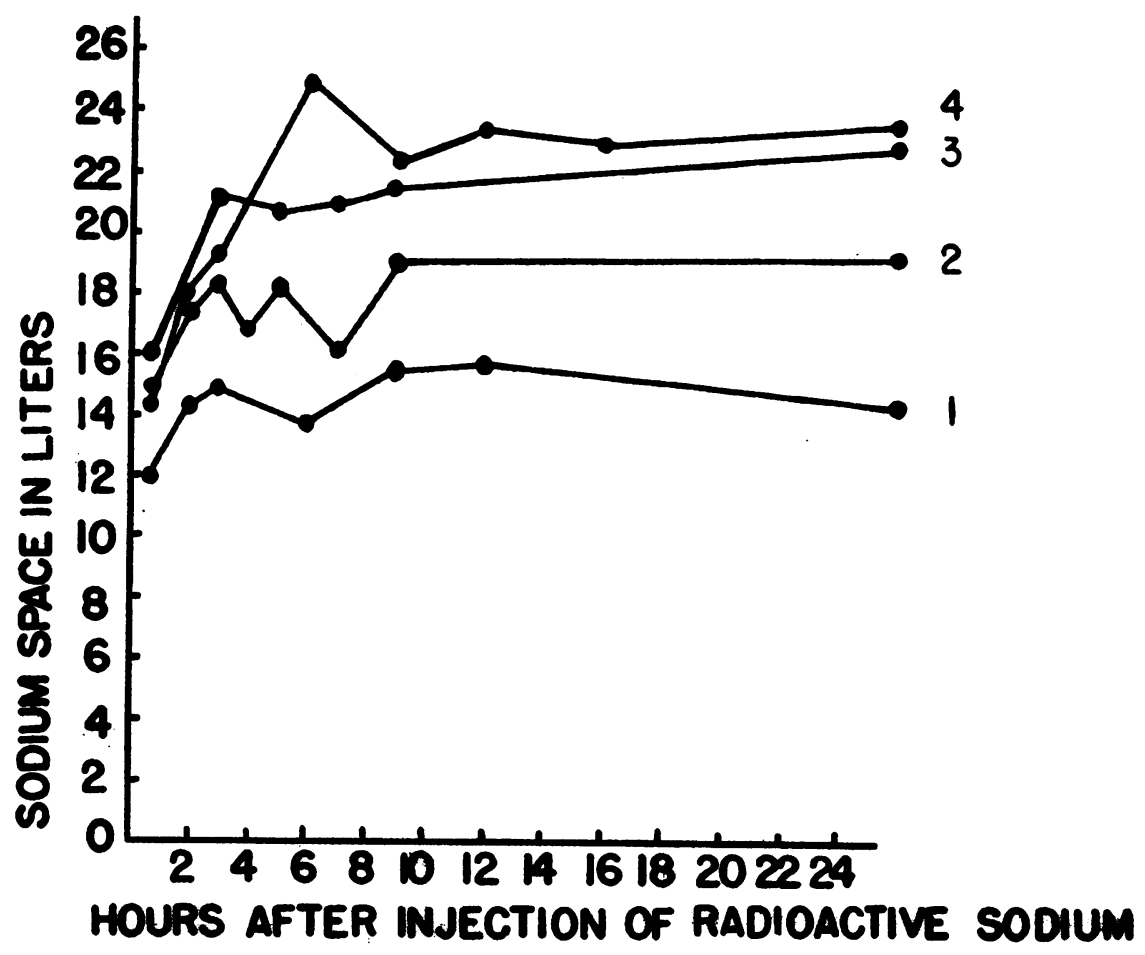

\section{1,2- Control \\ 3 - Laennec's Cirrhosis, No Edema or Ascites. 4 - Laennec's Cirrhosis, Ascifes.}

Fig. 1. Sodium Space at Intervals for 24 Hours following Injection of Na ${ }^{*}$ in Two Normal Subjects and in Two Patients with LaËnnec's Cirrhosis

Control : No. 1 Female, age 36 years, weight $57 \mathrm{Kg}$.

No. 2 Male, age 50 years, weight $55 \mathrm{Kg}$.

Cirrhosis: No. 3 Male, age 52 years, weight $73 \mathrm{Kg}$., no edema or ascites.

No. 4 Female, age 19, weight $57 \mathrm{Kg}$., with ascites, no edema. 
the three-hour sodium space. However, the expansion of sodium space from three hours to twenty-four hours in these patients and in 75 per cent of all patients in each of the two groups (control and cirrhotic) included in this study was less than 3 per cent of the body weight. The threehour sodium space has, therefore, been taken as the space at which equilibrium is reached in all such patients.

There are certain factors which change the level of sodium space independently of elapsed time after injection as can be seen by the changes in the sodium space after three hours which followed no consistent pattern. Meals seem to lower the sodium space and emotional stress seems to expand it. Since there are undoubtedly other unknown factors which affect it, it is imperative that a basal state be maintained during the test.

Patients with large amounts of ascites are not included in the study but patient No. 4 in Figure 1 is an example of the longer period required to achieve equilibrium in such cases. In this patient there was a steady increase of the sodium space in the first five hours after which there was little further expansion to the 24-hour determination.

\section{A. Fluid compartments in control subjects}

Table I summarizes results obtained on 22 control subjects. The average $\mathrm{T}-1824$ space was 4.0 per cent of body weight, the calculated blood volume 6.8 per cent of body weight, the three-hour sodium space 25.5 per cent of body weight and the total body water 54.5 per cent of body weight. The average figures for sodium space and total body water agree with those of other investigators (13, $14)$.

In the same table is shown the ratio of sodium space to total body water as well as the ratio of sodium space to body weight. The former figure eliminates fat which is the most variable compo-

TABLE I

Control patients: T-1824 space, calculated blood volume, sodium space, total body water, and total exchangeable sodium (volumes in per cent of body weight) *

\begin{tabular}{|c|c|c|c|c|c|c|c|c|c|c|}
\hline $\begin{array}{l}\text { Patient } \\
\text { no. }\end{array}$ & Sex & Age & Wt. & $\begin{array}{l}\text { T-1824 } \\
\text { space }\end{array}$ & $\begin{array}{l}\text { Calc. } \\
\text { blood } \\
\text { vol. }\end{array}$ & $\begin{array}{l}\text { Sodium } \\
\text { space } \\
(3-\mathrm{hr})\end{array}$ & $\begin{array}{l}\text { Sodium } \\
\text { space } \\
(24-\mathrm{hr})\end{array}$ & $\begin{array}{l}\text { Total } \\
\text { body } \\
\text { water }\end{array}$ & $\begin{array}{l}\text { Ratio 3-hr } \\
\text { sodium } \\
\text { space to } \\
\text { total body } \\
\text { water }\end{array}$ & $\begin{array}{c}\text { Total } \\
\text { exchange- } \\
\text { able } \\
\text { sodium }\end{array}$ \\
\hline $\begin{array}{r}1 \\
2 \\
3 \\
4 \\
5 \\
6 \\
7 \\
8 \\
9 \\
10 \\
11 \\
12 \\
13 \\
14 \\
15 \\
16 \\
17 \\
18 \\
19 \\
20 \\
21 \\
22\end{array}$ & $\begin{array}{l}F \\
M \\
M \\
F \\
F \\
M \\
F \\
M \\
M \\
F \\
F \\
F \\
M \\
F \\
F \\
M \\
M \\
M \\
F \\
M \\
M \\
F\end{array}$ & $\begin{array}{l}29 \\
21 \\
47 \\
23 \\
60 \\
52 \\
26 \\
54 \\
46 \\
35 \\
64 \\
41 \\
39 \\
25 \\
48 \\
18 \\
69 \\
65 \\
42 \\
38 \\
51 \\
41\end{array}$ & $\begin{array}{c}K g . \\
81.0 \\
72.4 \\
52.2 \\
54.7 \\
54.2 \\
65.5 \\
63.8 \\
64.3 \\
67.8 \\
64.0 \\
84.4 \\
64.2 \\
75.0 \\
59.8 \\
58.0 \\
52.8 \\
86.5 \\
49.7 \\
80.2 \\
73.2 \\
72.0 \\
66.4\end{array}$ & $\begin{array}{l}\% B W \\
3.2 \\
4.8 \\
3.6 \\
4.0 \\
3.6 \\
4.0 \\
4.1 \\
4.6 \\
4.0 \\
3.6 \\
3.1 \\
4.8 \\
4.3 \\
4.1 \\
4.5 \\
4.1 \\
3.1 \\
4.5 \\
3.1 \\
3.7 \\
4.5 \\
4.1\end{array}$ & $\begin{array}{l}\% B W \\
5.3 \\
8.8 \\
6.1 \\
6.4 \\
7.6 \\
7.3 \\
6.9 \\
7.8 \\
6.5 \\
6.5 \\
4.9 \\
6.7 \\
7.1 \\
7.1 \\
7.5 \\
6.5 \\
6.4 \\
7.5 \\
6.0 \\
6.7 \\
7.6 \\
6.5\end{array}$ & $\begin{array}{c}\% B W \\
25.4 \\
29.9 \\
26.4 \\
27.6 \\
26.7 \\
26.4 \\
28.2 \\
29.8 \\
25.8 \\
19.6 \\
24.2 \\
28.0 \\
25.7 \\
25.2 \\
27.0 \\
23.6 \\
27.2 \\
20.1 \\
22.2 \\
26.4 \\
20.0\end{array}$ & $\begin{array}{c}\% B W \\
25.1 \\
30.6 \\
27.5 \\
25.3 \\
29.4 \\
27.8 \\
30.2 \\
33.3 \\
28.2 \\
31.6 \\
30.9 \\
29.2 \\
27.9 \\
30.3 \\
25.9 \\
30.2 \\
20.7 \\
- \\
-\end{array}$ & $\begin{array}{l}\% B W \\
49.8 \\
60.2 \\
51.0 \\
55.6 \\
51.0 \\
51.0 \\
51.1 \\
59.0 \\
65.3 \\
54.5 \\
38.3 \\
56.8 \\
58.5 \\
57.4 \\
49.7 \\
67.7 \\
50.5 \\
58.3 \\
43.8 \\
54.4 \\
59.1 \\
46.8\end{array}$ & $\begin{array}{l}\% \\
51.0 \\
49.7 \\
51.8 \\
45.5 \dagger \\
53.0 \\
54.5 \\
51.2 \\
47.2 \\
45.6 \\
47.2 \\
51.3 \\
49.7 \\
47.8 \\
45.0 \\
50.8 \\
40.1 \\
46.8 \\
46.6 \\
45.7 \\
41.0 \\
44.6 \\
42.5\end{array}$ & $\begin{array}{c}m E q . / K g \\
34.4 \\
42.0 \\
34.6 \\
38.0 \\
42.6 \\
35.8 \\
41.5 \\
46.4 \\
39.1 \\
44.6 \\
42.9 \\
40.8 \\
37.6 \\
44.8 \\
36.1 \\
41.5 \\
28.9 \\
- \\
- \\
-\end{array}$ \\
\hline \multicolumn{3}{|c|}{$\begin{array}{l}\text { Average } \\
\text { Standard deviation }\end{array}$} & & $\begin{array}{l}4.0 \\
0.5\end{array}$ & $\begin{array}{l}6.8 \\
0.9\end{array}$ & $\begin{array}{r}25.5 \\
2.9\end{array}$ & 28.5 & $\begin{array}{r}54.5 \\
6.6\end{array}$ & $\begin{array}{r}47.7 \\
3.8\end{array}$ & $\begin{array}{r}39.5 \\
4.5\end{array}$ \\
\hline
\end{tabular}
reasons.

* Where a dash appears instead of a figure, the determination was not performed or was unsatisfactory for technical

$\dagger$ For calculation of this ratio the 24-hour sodium space was used because the 3-hour sodium space was unsatisfactory. The determination was not included in the calculation of standard deviation.

† Standard deviations determined by taking the square root of the sum of the squares of the differences between the observations in the series and the mean of the series divided by the number minus one. 
TABLE II

Patients with cirrhosis: T-1824 space, calculated blood volume, sodium space, and total body water (volume in per cent of body weight)

\begin{tabular}{|c|c|c|c|c|c|c|c|c|c|c|c|c|c|}
\hline $\begin{array}{l}\text { Patient } \\
\text { no. }\end{array}$ & $\begin{array}{l}\text { Sex } \\
\text { Age }\end{array}$ & Weight & $A / G$ & $\begin{array}{l}\text { Clinical } \\
\text { edema }\end{array}$ & $\begin{array}{c}\text { Ascites } \\
\text { on } \\
\text { admission }\end{array}$ & $\begin{array}{l}\text { Salt } \\
\text { in } \\
\text { diet* }\end{array}$ & $\begin{array}{l}\text { T-1824 } \\
\text { space }\end{array}$ & $\begin{array}{c}\text { Calc. } \\
\text { blood } \\
\text { vol. }\end{array}$ & $\begin{array}{c}\text { Sodium } \\
\text { space } \\
\text { (3-hr) }\end{array}$ & $\begin{array}{c}\text { Sodium } \\
\text { space } \\
\text { (24-hr) }\end{array}$ & $\begin{array}{l}\text { Total } \\
\text { body } \\
\text { water }\end{array}$ & $\begin{array}{l}\text { Ratio } \\
\text { 3 hours } \\
\text { sodium } \\
\text { space } \\
\text { to total } \\
\text { body } \\
\text { water }\end{array}$ & $\begin{array}{c}\text { Total } \\
\text { exchange- } \\
\text { abble } \\
\text { sodium }\end{array}$ \\
\hline & & $K_{g}$ & & & & $m E q$ & $\% B W$ & $\% B W$ & $\% B W$ & $\% B W$ & $\% B W$ & $\%$ & $m E q_{.} / K_{\boldsymbol{g}}$ \\
\hline \multicolumn{14}{|c|}{ Group $A$} \\
\hline $\begin{array}{l}1 \\
2 \\
3 \\
4 \\
5 \\
6 \\
7 \\
8 \\
9\end{array}$ & $\begin{array}{l}\text { M49 } \\
\text { M55 } \\
\text { F 51 } \\
\text { M48 } \\
\text { M46 } \\
\text { M42 } \\
\text { M26 } \\
\text { M60 } \\
\text { F 55 }\end{array}$ & $\begin{array}{l}70.0 \\
53.8 \\
75.6 \\
67.0 \\
68.6 \\
68.5 \\
64.1 \\
75.2 \\
84.2\end{array}$ & $\begin{array}{l}2.9 / 3.8 \\
3.2 / 4.1 \\
4.0 / 3.3 \\
3.5 / 3.1 \\
4.1 / 3.2 \\
3.8 / 3.1 \\
5.1 / 2.7 \\
2.6 / 3.7 \\
2.1 / 3.0\end{array}$ & $\begin{array}{l}+ \\
0 \\
0 \\
0 \\
0 \\
0 \\
0 \\
+ \\
+\end{array}$ & $\begin{array}{l}0 \\
0 \\
0 \\
0 \\
0 \\
0 \\
0 \\
0 \\
0\end{array}$ & $\begin{array}{c}52.5 \\
17.5 \\
\mathrm{U} \\
17.5 \\
17.5 \\
\mathrm{U} \\
\mathrm{U} \\
\mathrm{U} \\
52.5\end{array}$ & $\begin{array}{l}5.0 \\
5.4 \\
5.0 \\
6.5 \\
5.4 \\
5.7 \\
4.5 \\
6.2 \\
6.5\end{array}$ & $\begin{array}{r}8.4 \\
8.1 \\
6.7 \\
10.5 \\
8.5 \\
8.6 \\
6.4 \\
10.5 \\
9.3\end{array}$ & $\begin{array}{l}30.7 \\
29.2 \\
27.0 \\
30.8 \\
28.5 \\
32.4 \\
33.8 \\
31.9 \\
37.4\end{array}$ & $\begin{array}{l}30.4 \\
30.5 \\
29.9 \\
35.0 \\
30.6 \\
35.5 \\
34.6 \\
34.3 \\
38.0\end{array}$ & $\begin{array}{l}60.5 \\
55.9 \\
50.1 \\
58.7 \\
63.6 \\
59.5 \\
52.0 \\
65.3 \\
54.0\end{array}$ & $\begin{array}{l}50.8 \\
52.3 \\
54.0 \\
52.5 \\
53.2 \\
54.5 \\
65.0 \\
49.2 \\
70.4\end{array}$ & $\begin{array}{l}40.6 \\
40.3 \\
40.8 \\
47.0 \\
4 \overline{45.4} \\
41.7 \\
48.4 \\
55.0\end{array}$ \\
\hline \multicolumn{14}{|c|}{ Group $B \ddagger$} \\
\hline $\begin{array}{l}10 \\
11 \\
12 \\
13 \\
14 \\
15\end{array}$ & $\begin{array}{l}\text { F 41 } \\
\text { M62 } \\
\text { M70 } \\
\text { M53 } \\
\text { M49 } \\
\text { M58 }\end{array}$ & $\begin{array}{l}52.5 \\
79.6 \\
69.6 \\
57.0 \\
75.0 \\
81.0\end{array}$ & $\begin{array}{l}4.1 / 2.2 \\
2.9 / 4.6 \\
3.1 / 2.3 \\
3.0 / 3.1 \\
4.0 / 2.2 \\
3.0 / 3.7\end{array}$ & $\begin{array}{c}0 \\
0 \\
++ \\
0 \\
+ \\
+\end{array}$ & $\begin{array}{c}+ \\
+ \\
++ \\
+ \\
+++ \\
+++\end{array}$ & $\begin{array}{c}17.5 \\
17.5 \\
U \\
17.5 \\
17.5 \\
52.5\end{array}$ & $\begin{array}{l}7.0 \\
5.6 \\
4.8 \\
4.6 \\
5.9 \\
4.0\end{array}$ & $\begin{array}{r}11.8 \\
8.1 \\
8.7 \\
8.1 \\
10.0 \\
6.8\end{array}$ & $\begin{array}{l}33.2 \\
31.9 \\
45.9 \\
42.5 \\
43.9 \\
33.4\end{array}$ & $\begin{array}{l}37.2 \\
29.6 \\
45.6 \\
41.2 \\
42.3 \\
37.5\end{array}$ & $\begin{array}{l}58.5 \\
51.5 \\
66.2 \\
63.0 \\
82.6 \\
63.7\end{array}$ & $\begin{array}{l}56.9 \\
62.0 \\
69.3 \\
67.5 \\
57.2 \\
52.4\end{array}$ & $\begin{array}{l}51.4 \\
37.7 \\
58.9 \\
56.0 \\
55.0 \\
44.4\end{array}$ \\
\hline \multicolumn{5}{|c|}{$\begin{array}{l}\text { Average Nos. } 1-9 \text { (Group A) } \\
\text { Standard deviation } \$\end{array}$} & & & $\begin{array}{l}5.6 \\
0.7\end{array}$ & $\begin{array}{l}8.6 \\
1.4\end{array}$ & $\begin{array}{r}31.2 \\
3.1\end{array}$ & 33.3 & $\begin{array}{r}57.8 \\
5.0\end{array}$ & $\begin{array}{r}55.9 \\
6.6\end{array}$ & $\begin{array}{r}44.9 \\
7.8\end{array}$ \\
\hline \multicolumn{5}{|c|}{$\begin{array}{l}\text { Average Nos. 10-15 (Group B) } \\
\text { Standard deviation } \S\end{array}$} & & & $\begin{array}{l}5.3 \\
1.1\end{array}$ & $\begin{array}{l}8.9 \\
1.8\end{array}$ & $\begin{array}{r}38.5 \\
6.3\end{array}$ & 38.7 & $\begin{array}{l}64.2 \\
10.3\end{array}$ & $\begin{array}{r}60.9 \\
6.3\end{array}$ & $\begin{array}{r}50.7 \\
8.0\end{array}$ \\
\hline
\end{tabular}

* $U$ indicates unrestricted salt diet. reasons.

$\dagger$ When a dash appears instead of a figure the determination was not performed or was unsatisfactory for technical

$\ddagger$ All patients in group B except No. 13 had had paracentesis within two weeks of the test. The days elapsed since the last paracentesis, the number of liters removed, and the increase of body weight if any in the intervening period are as follows:
No. 10
No. 11
No. 12
No. 14
$1.5 \mathrm{~L}$. ascitic fluid removed 1 week before, no weight gain.
$2.2 \mathrm{~L}$. ascitic fluid removed 5 days before, no weight gain. $4.8 \mathrm{~L}$. ascitic fluid removed 2 weeks before, no weight gain. $20.9 \mathrm{~L}$. ascitic fluid removed 1 week before, $2.3 \mathrm{Kg}$. weight gain.
No. $15 \quad 6.6 \mathrm{~L}$. ascitic fluid removed 2 weeks before, $6.6 \mathrm{Kg}$. weight gain.

8 Calculated as in Table I.

nent of the soft tissue (15). This ratio fell within the limits of 40 per cent and 55 per cent in the control subjects with an average of 47.7 per cent. In all but four control patients it fell between the levels of 45 per cent and 55 per cent.

Total exchangeable sodium in $\mathrm{mEq}$. per $\mathrm{Kg}$. depends on the ratio of radioactive sodium to natural sodium after equilibration with all available body sodium has occurred. It differed markedly from one patient to another. The range fell between 29 and $46 \mathrm{mEq}$. per $\mathrm{Kg}$. with an average of $39.5 \mathrm{mEq}$. per $\mathrm{Kg}$. body weight.

\section{B. Fluid compartments in patients with Laënnec's cirrhosis}

Results of tests on patients with cirrhosis are summarized in Table II. These fall into two groups. The first, group A, consists of nine patients who had no detectable ascites but three of whom had clinical edema. The remaining six patients, group B, had ascites and three of these had clinical edema. The patients in group B are listed approximately in order of increasing ascitic fluid on admission. All patients in this group except No. 
13 had had paracenteses within two weeks of the study. Thus, at the time of the test, none had more than a moderate amount of ascites. Dividing the cirrhotic patients in this way tends to group them according to severity of their disease in so far as the presence of ascites determines the severity of cirrhosis. It separates the patients into known cirrhotics who do not retain salt and water and those who do.

In the series of patients with ascites included in this study, it was not possible to prove that equilibrium had been reached by simultaneous plasma and ascitic fluid sampling at three hours. ${ }^{3}$ However, the relationship between the 3-hour and 24-hour space determinations in the patients in

8 In studies not included in the present paper paracentesis was performed on six patients five hours after injection of radioactive sodium, the total volume of ascitic fluid withdrawn being, respectively, $1.1 \mathrm{~L}$., $1.3 \mathrm{~L}$., $2.9 \mathrm{~L}$., 4.8 L., $5.7 \mathrm{~L}$., and $9.8 \mathrm{~L}$. Simultaneous sampling of plasma and ascitic fluid at that time showed equilibrium in the first five patients, but not in the sixth. There was no way of knowing how much sooner than five hours equilibration had occurred.

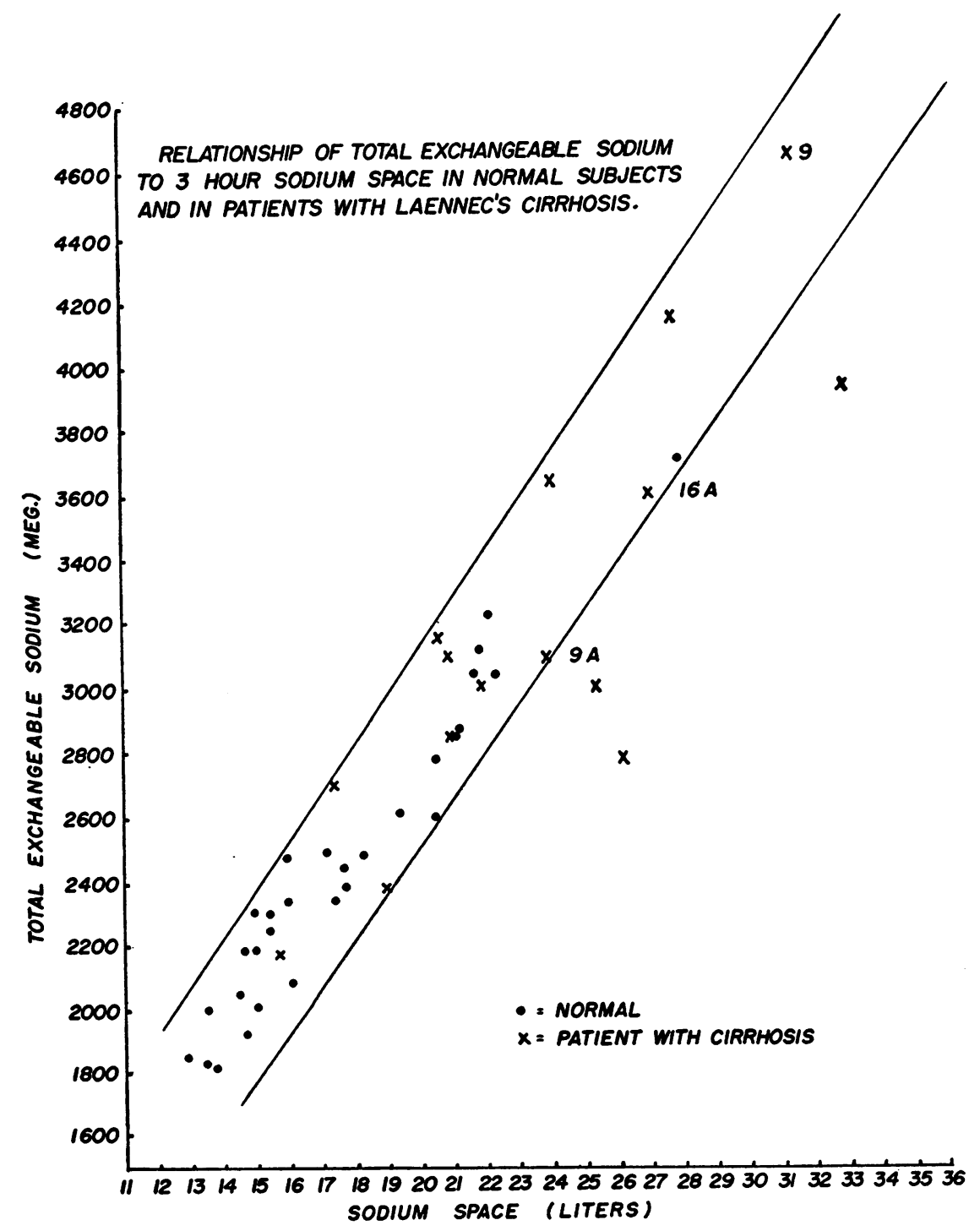

Fig. 2. Relationship of Total Exchangeable Sodium to Three-Hour Sodium Space in Normal Subjects and in Patients with Lä̈nnec's Cirrhosis 
group B was consistent with that found in the other groups.

The average $T-1824$ space in groups $A$ and $B$ was 5.6 per cent and 5.3 per cent of body weight and the calculated blood volume was 8.6 per cent and 8.9 per cent of body weight, respectively. These averages indicate that blood and plasma volumes in cirrhosis are elevated above those in the control subjects shown in Table I, but that the blood and plasma volumes are not significantly affected by the presence or absence of ascites. There is a great variation of plasma and blood volume from one cirrhotic patient to another. Three of the patients had values that were within the range of the control patients.

The three-hour sodium space in patients with cirrhosis was significantly higher than the control. The averages for groups $A$ and $B$ were 31.2 per cent and 38.5 per cent of the body weight, respectively. When comparing the cirrhotic patients without ascites (group A) with the control the $t$ value is 4.8, well above the $t$ value of 2.763 at which there is a 1 per cent probability that the two groups were taken from the same population. When the cirrhotic patients with ascites (group B) are compared with the controls the $t$ value is 4.7.

The average total body water was somewhat higher in patients with cirrhosis than in the con- trol cases but not significantly so by statistical analysis. In the present series it was $\mathbf{5 7 . 8}$ per cent and 64.2 per cent of body weight in the two cirrhotic groups compared to 54.5 per cent of body weight in the control group. The $t$ value for groups A and B when compared with the control figures was 1.34 and 2.96 , respectively. The results for total body water in cirrhosis are somewhat higher in the present series than in a similar but smaller series in which tritium was utilized (16).

When the patients in the control group are compared with the cirrhotic group they are not perfectly matched with respect to age and sex. There is a slight downward trend of sodium and deuterium oxide space with age, and these spaces tend to be slightly larger in the male than in the female. The differences noted with age and sex may be secondary to body habitus and possibly other unknown factors. However, when the sodium space is plotted against total body water (see Table I and II, next to last column) the age, sex and other factors are eliminated and ideal conditions exist for statistical analysis of the results in the two groups. The $t$ value when controls and group A are compared is 4.2 , and when controls and group $\mathrm{B}$ are compared, 6.4. Both these figures show a high probability that the controls and the cirrhotic patients were selected from different populations.

The total exchangeable sodium was increased in

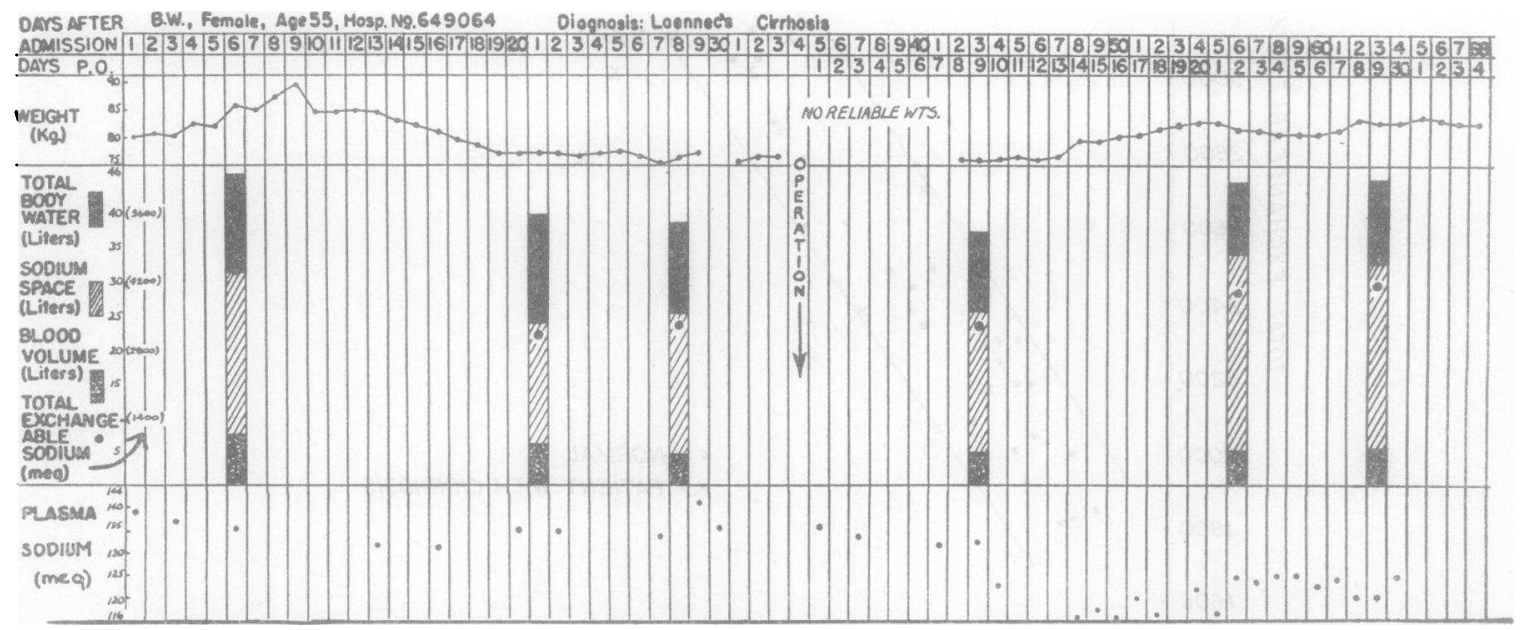

Fig. 3. Water Changes in a Cirrhotic Patient following Sodium Restriction, Diuretics and a Portacaval Shunt (Patient B. W., Female, 55 Years)

Total body water, sodium space, and blood volume are charted on the same column. Total exchangeable sodium is superimposed on this column with a secondary scale. 
cirrhosis and was greater in patients with edema and ascites. The control average was $40 \mathrm{mEq}$. per $\mathrm{Kg}$. The average of eight patients without ascites was $44.9 \mathrm{mEq}$. per $\mathrm{Kg}$., and of six patients with ascites $50.7 \mathrm{mEq}$. per $\mathrm{Kg}$.

\section{Relationship of total exchangeable sodium to sodium space}

Figure 2 represents the relationship of the threehour sodium space in liters (the abscissa) to the total exchangeable sodium in milliequivalents (the ordinate) for 29 control subjects and 12 patients with cirrhosis. In spite of the abnormal collection of edema and ascites in some of the patients with cirrhosis the sodium space and total exchangeable sodium are related in such a way that they fall in the band of control values although they tend to fall higher on the curve due to the presence of excessive fluid. For example, patient No. 9 entered the hospital with gross edema, and No. 16 with marked ascites. After a few days on a low salt diet and diuretics, No. 9 came down to a point shown as $9 \mathrm{~A}$, and No. 16, whose original figure of $43.3 \mathrm{~L}$. sodium space and $5,840 \mathrm{mEq}$. exchangeable sodium was too high to put on this figure, showed a fall of sodium space and total exchangeable sodium to the point shown as 16A. Three cirrhotic patients having ascites fell slightly below the area which is marked off as the control level, that is, the sodium content of the body was low in relation to the sodium space. This was accounted for in two of these patients by the fact that the ascitic fluid had a sodium content lower than the corresponding plasma. Paracentesis was not done in the third. The sodium level in the ascitic fluid was equal to that in plasma in the cirrhotic patients with ascites whose ratio fell in the control band. This experiment is important from the point of view of validating the sodium space method in patients who have known salt and fluid abnormalities. Proof such as is given here is required to show that the total exchangeable sodium pool is related to the sodium space in patients with Laënnec's cirrhosis as it is in the normal (see Appendix).

\section{DISCUSSION}

The use of radioactive sodium for measuring changes in extracellular fluid volume is simpler than available methods for measuring extracellular fluid space but has the disadvantage that a substantial portion of the space measured is intracellular or transcellular (18). Within three hours after injection the radioactive sodium is considered to have been distributed and equilibrated throughout the greater part of the total sodium space volume in non-edematous states because of the fact that very little increase of space occurs between 3 and 24 hours. The facts that serial sodium space determinations on patients who are in balance are highly reproducible and that there is good agreement between sodium space, total body water, and weight changes in patients who have had gross water changes indicate that the non-extracellular components of the sodium space are relatively constant in any particular case.

Evidence of the reproducibility of results by the sodium $^{24}$ method is given in Table III, which presents the data from serial studies at weekly intervals on patients having a variety of abnormalities. The body weight changed somewhat in a few of these patients but the three hour sodium space as percentage of total body weight varied only between 0 and 2.2 per cent, well within the errors of the method. The plasma and blood volume determinations by the T-1824 dilution method, on the other hand, appear to change greatly from one week to another without parallel changes in other compartments.

The data above suggest that water and salt retention in cirrhosis is confined to the fluid space that is measured by the dilution of radioactive sodium. The data do not give absolute evidence whether the abnormal fluid changes in cirrhosis are confined to the anatomical extracellular space or are partially intracellular in view of the fact that about one-third of the sodium space is intracellular or transcellular. Indirect evidence lies in the finding that the ratio of sodium space to total exchangeable sodium is similar in controls and cirrhotic patients. Furthermore the intracellular space not included in the sodium space, as calculated by subtracting the sodium space from the deuterium space, is not increased in cirrhotic patients.

There is a significant increase of sodium space and total body water in patients with cirrhosis whether ascites is present or not. This finding should be of value in the diagnosis of Laënnec's cirrhosis. Whether the findings here are related to the presence of subclinical edema and ascites, or 
are due specifically to the disease itself is not known at present due to lack of information on patients with edema and ascites from causes other than Laënnec's cirrhosis. In spite of the partially intracellular nature of the sodium space, the method is of value in following the degree of hydration in patients with abnormal accumulations of fluid.

\section{SUMMARY}

Plasma volume as indicated by the T-1824 space, calculated blood volume, radioactive sodium ( $\left.\mathrm{Na}^{24}\right)$ space, and deuterium oxide space have been studied in twenty-two control subjects and fifteen patients with Laënnec's cirrhosis. These spaces are increased in Laënnec's cirrhosis over the average control level. The increase of sodium space is greater when edema and ascites are apparent. Al- though the sodium space is known to include other components as well as the extracellular space it seems to reflect consistently and reproducibly the changes in body hydration induced by Laënnec's cirrhosis.

\section{APPENDIX}

\section{Illustrative cases}

Patient No. 9 (B. W.) Figure 3. On admission this 55-year old, obese, white female had been bleeding from oesophageal varices. There was moderate edema and some ascites. The weight was $84.2 \mathrm{Kg}$. Blood losses were replaced in the first week after admission by transfusions. A low salt diet was then instituted and mercuhydrin was given intramuscularly at the rate of $3 \mathrm{ml}$. a week. In two weeks the weight loss was $8.4 \mathrm{Kg}$. which was accompanied by a $7.5 \mathrm{~L}$. fall in sodium space and $5.7 \mathrm{~L}$. fall in total body water. These figures suggest that the

TABLE III

Reproducibility of sodium space in subjects studied several times at weekly intervals

\begin{tabular}{|c|c|c|c|c|c|c|c|}
\hline $\begin{array}{l}\text { Patient } \\
\text { no. }\end{array}$ & Diagnosis & Sex & Age & Weight & $\begin{array}{c}\text { Plasma } \\
\text { vol. }\end{array}$ & $\begin{array}{l}\text { Blood } \\
\text { vol. }\end{array}$ & $\begin{array}{l}\text { Sodium } \\
\text { space } \\
\text { (3 hrs.) }\end{array}$ \\
\hline 1 & $\begin{array}{l}\text { Gastrointestinal } \\
\text { bleeding }\end{array}$ & $\mathbf{M}$ & 64 & $\begin{array}{l}61.7 \\
61.0\end{array}$ & $\begin{array}{c}\% B W \\
4.4 \\
4.2\end{array}$ & $\begin{array}{c}\text { \% BW } \\
7.2 \\
6.5\end{array}$ & $\begin{array}{c}\text { \% BW } \\
29.1 \\
30.3\end{array}$ \\
\hline 2 & $\begin{array}{l}\text { Gastrointestinal } \\
\text { bleeding }\end{array}$ & F & 60 & $\begin{array}{l}54.2 \\
54.4\end{array}$ & $\begin{array}{l}3.7 \\
4.8\end{array}$ & $\begin{array}{l}7.6 \\
8.3\end{array}$ & $\begin{array}{l}27.6 \\
29.8\end{array}$ \\
\hline 3 & $\begin{array}{l}\text { Carcinoma } \\
\text { stomach }\end{array}$ & $\mathbf{M}$ & 62 & $\begin{array}{l}39.7 \\
37.7\end{array}$ & $\begin{array}{l}6.2 \\
7.0\end{array}$ & $\begin{array}{l}10.7 \\
12.3\end{array}$ & $\begin{array}{l}40.6 \\
41.2\end{array}$ \\
\hline 4 & $\begin{array}{l}\text { Laënnec's cirrhosis } \\
\text { compensated }\end{array}$ & F & 51 & $\begin{array}{l}70.7 \\
75.6 \\
75.8 \\
73.3 \\
73.0\end{array}$ & $\begin{array}{l}3.5 \\
5.0 \\
4.3 \\
4.0 \\
4.9\end{array}$ & $\begin{array}{l}5.1 \\
6.7 \\
7.1 \\
5.7 \\
7.1\end{array}$ & $\begin{array}{l}26.9 \\
27.0 \\
27.4 \\
27.8 \\
26.6\end{array}$ \\
\hline 5 & $\begin{array}{l}\text { Laënnec's cirrhosis } \\
\text { compensated }\end{array}$ & $\mathbf{M}$ & 48 & $\begin{array}{l}67.0 \\
67.0\end{array}$ & $\begin{array}{l}6.5 \\
5.2\end{array}$ & $\begin{array}{r}10.5 \\
8.0\end{array}$ & $\begin{array}{l}30.8 \\
32.1\end{array}$ \\
\hline 6 & $\begin{array}{l}\text { Subdiaphragmatic } \\
\text { abscess }\end{array}$ & F & 46 & $\begin{array}{l}57.4 \\
56.1\end{array}$ & $\begin{array}{l}4.9 \\
4.4\end{array}$ & $\begin{array}{l}6.8 \\
7.5\end{array}$ & $\begin{array}{l}31.4 \\
30.6\end{array}$ \\
\hline 7 & $\begin{array}{l}\text { Appendiceal } \\
\text { abscess }\end{array}$ & $\mathbf{M}$ & 45 & $\begin{array}{l}60.8 \\
59.4\end{array}$ & $\begin{array}{l}4.9 \\
5.2\end{array}$ & $\begin{array}{l}7.6 \\
7.7\end{array}$ & $\begin{array}{l}39.0 \\
39.4\end{array}$ \\
\hline 8 & $\begin{array}{l}\text { Carcinoma } \\
\text { cervix }\end{array}$ & $\mathbf{F}$ & 46 & $\begin{array}{l}51.4 \\
49.4\end{array}$ & $\begin{array}{l}6.2 \\
5.1\end{array}$ & $\begin{array}{l}9.8 \\
8.3\end{array}$ & $\begin{array}{l}30.4 \\
29.1\end{array}$ \\
\hline 9 & $\begin{array}{l}\text { Carcinoma } \\
\text { cervix }\end{array}$ & $\mathbf{F}$ & 34 & $\begin{array}{l}47.8 \\
47.2\end{array}$ & $\begin{array}{l}5.2 \\
4.5\end{array}$ & $\begin{array}{l}8.2 \\
7.4\end{array}$ & $\begin{array}{l}27.0 \\
28.6\end{array}$ \\
\hline 10 & $\begin{array}{l}\text { Carcinoma } \\
\text { cervix }\end{array}$ & F & 41 & $\begin{array}{l}61.0 \\
61.0\end{array}$ & $\begin{array}{l}4.6 \\
3.5\end{array}$ & $\begin{array}{l}7.2 \\
5.1\end{array}$ & $\begin{array}{l}26.2 \\
26.0\end{array}$ \\
\hline 11 & $\begin{array}{l}\text { Mitral valvulotomy } \\
\text { post-op. } 5 \text { and } 12 \text { days }\end{array}$ & F & 35 & $\begin{array}{l}56.0 \\
56.3\end{array}$ & $\begin{array}{l}3.9 \\
5.3\end{array}$ & $\begin{array}{l}5.5 \\
7.8\end{array}$ & $\begin{array}{l}25.4 \\
25.9\end{array}$ \\
\hline 12 & $\begin{array}{l}\text { Glomerular } \\
\text { nephritis }\end{array}$ & $\mathbf{F}$ & 40 & $\begin{array}{l}56.0 \\
56.2\end{array}$ & $\begin{array}{l}7.9 \\
7.8\end{array}$ & $\begin{array}{l}9.8 \\
9.6\end{array}$ & $\begin{array}{l}40.1 \\
42.5\end{array}$ \\
\hline
\end{tabular}


TABLE IV

Patient No. 13-Correlation of course of liver disease with weight, fluid compartments and sodium changes

\begin{tabular}{|c|c|c|c|c|c|c|c|c|c|c|c|c|}
\hline \multirow{2}{*}{$\begin{array}{l}\text { Date } \\
12 / 9 \\
12 / 16\end{array}$} & \multirow{2}{*}{ Postop. } & \multirow{2}{*}{$\begin{array}{c}\text { Operation } \\
\text { Portacaval } \\
\text { shunt }\end{array}$} & \multirow{2}{*}{$\begin{array}{c}\text { Wt. } \\
\text { Kg. } \\
59 \\
57\end{array}$} & \multirow[t]{2}{*}{ Ascites } & \multirow{2}{*}{$\begin{array}{c}\begin{array}{c}\text { Approx. } \\
\text { daily } \\
\text { salt } \\
\text { intake }\end{array} \\
m E q . \\
52.5\end{array}$} & \multicolumn{2}{|c|}{$\begin{array}{c}\text { Sodium space } \\
\text { (3 hours) }\end{array}$} & \multicolumn{2}{|c|}{$\begin{array}{c}\text { Total body } \\
\text { water }\end{array}$} & \multirow{2}{*}{$\begin{array}{c}\begin{array}{c}\text { Plasma } \\
\mathrm{Na}\end{array} \\
m E q . / L . \\
132\end{array}$} & \multicolumn{2}{|c|}{$\begin{array}{l}\text { Total exchange- } \\
\text { able sodium }\end{array}$} \\
\hline & & & & & & $\begin{array}{c}L . \\
26.2\end{array}$ & $\begin{array}{c}\% B W \\
44.4\end{array}$ & $L$. & $\% B W$ & & $\begin{array}{l}m E q . \\
3,530\end{array}$ & $\begin{array}{c}m E q . / K g . \\
60\end{array}$ \\
\hline $\begin{array}{c}12 / 17 \\
1 / 8\end{array}$ & $\begin{array}{r}1 \\
23\end{array}$ & & $\begin{array}{l}57 \\
57.7\end{array}$ & & $\begin{array}{l}52.5 \\
17.5\end{array}$ & 24.2 & 42.5 & 35.9 & 63.0 & 134 & 3,140 & 56 \\
\hline $\begin{array}{l}1 / 28 \\
2 / 3 \\
2 / 22\end{array}$ & $\begin{array}{l}43 \\
49 \\
68\end{array}$ & Abdominal & $\begin{array}{l}52.2 \\
51.6 \\
48.8\end{array}$ & $\stackrel{+}{0}$ & $\begin{array}{l}17.5 \\
17.5 \\
52.5\end{array}$ & 26.7 & $\begin{array}{r}51.2 \\
.\end{array}$ & & & 137 & 3,510 & 67 \\
\hline $3 / 3$ & 77 & Hanice & 48.6 & 0 & 52.5 & 20.1 & 41.4 & 31.4 & 64.5 & 139 & 2,860 & 59 \\
\hline
\end{tabular}

greater part of the weight loss was due to loss of fluid. Edema and ascites diminished but did not disappear entirely. Prolonging salt restriction did not effect any further loss of fluid and a portacaval shunt was performed on the 34th day after admission. The weight remained at $75 \mathrm{Kg}$. from 13 days before operation until 9 days after operation and the sodium space and total body water did not change. On the tenth postoperative day plasma sodium, chloride and albumin to globulin ratio were 123 mEq. per L., $88 \mathrm{mEq}$. per L., and $2.3 / 4.2$, respectively. On that day two grams of sodium chloride were given orally in addition to her diet, and from the twelfth to the twenty-second postoperative day a total of $85 \mathrm{Gm}$. of salt free albumin and $450 \mathrm{ml}$. of 5 per cent saline was administered. During this time the body weight rose from $75.0 \mathrm{Kg}$. to $81.2 \mathrm{Kg}$. and edema and ascites increased. Sodium space and total body water rose $7.3 \mathrm{~L}$. and $7.2 \mathrm{~L}$., respectively. The plasma sodium dropped to $115 \mathrm{mEq}$. per L. on postoperative day 14 and gradually returned to $124 \mathrm{mEq}$. per L. by the 21st postoperative day. An effort was made to remove some of the excess fluid with continued low salt diet but the patient was discharged soon afterward having a weight, sodium space, and total body water similar to that on admission. The administration of salt in this patient probably hastened the reappearance of water and sodium retention.

Patient No. 13 (F. M.), Table IV. This 53-year old white male is an example of a patient with bleeding oesophageal varices and ascites whose fluid compartments were followed at irregular intervals over the course of three months. Seven days prior to the portacaval shunt there was a severe hemorrhage and coma. The portacaval shunt was accomplished within two days of recovery from coma. The course was a difficult one due to unexplained small bowel bleeding and to several abdominal abscesses. Three liters of purulent ascitic fluid were drained from an intra-abdominal abscess on the 68 th postoperative day.

The patient had a sodium space of 44 per cent of body weight on admission. The total body water was 63 per cent of the body weight which did not seem to be excessive for his thin, small body. On the first day following the portacaval shunt the sodium space and the body weight agreed in that there was a two $\mathrm{Kg}$. loss. Forty-three days postoperatively the patient had lost $4.8 \mathrm{Kg}$. in body weight but the sodium space had not changed. From this fact plus the increase of ascites it may be assumed that the total body water had not decreased between the first and 43rd day although a determination of total body water on the 43rd day was not available. The fall in weight was, therefore, probably due to a loss in body tissue. Until the 43rd day little improvement occurred in the direction of a reduction of excessive fluids. From the 43rd to the 77 th postoperative day the patient lost $6.4 \mathrm{Kg}$. of body weight. The sodium space diminished by $6.6 \mathrm{~L}$., the total exchangeable sodium by $650 \mathrm{mEq}$, and the total body water probably declined at least $4.5 \mathrm{~L}$., suggesting that the weight loss was due to loss of fluid rather than of tissue. During the same period the plasma sodium level had increased slightly, indicating improvement in the liver disease (17). The absence of detectable ascites at the end of the three-month period substantiates this. At present there is no good explanation for the persisting high sodium space in this patient even when no detectable fluid accumulation was present.

\section{ACKNOWLEDGMENTS}

The technical assistance of Miss Bebe Mensch and Mrs. Marianne Loser is gratefully acknowledged. The authors are indebted to Dr. Albert J. Paquin, Jr. for his interest and helpful suggestions in the preparation of this manuscript.

\section{REFERENCES}

1. Eisenmenger, W. J., Rôle of sodium in the formation and control of ascites in patients with cirrhosis. Ann. Int. Med., 1952, 37, 261.

2. Eisenmenger, W. J., Blondheim, S. H., Bongiovanni, A. M., and Kunkel, H. G., Electrolyte studies on patients with cirrhosis of the liver. J. Clin. Invest., $1950,29,1491$. 
3. Ricketts, W. E., Eichelberger, L., and Kirsner, J. B., Observations on the alterations in electrolytes and fluid balance in patients with cirrhosis of the liver with and without ascites. J. Clin. Invest., 1951, 30, 1157.

4. Gordon, E. S., Chart, J. J., and Meyer, E. S., The importance of a 'sodium retaining factor' in the urine in the mechanism of edema formation. J. Clin. Invest., 1952, 31, 633.

5. Ralli, E. P., Robson, J. S., Clarke, D., and Hoagland, C. L., Factors influencing ascites in patients with cirrhosis of the liver. J. Clin. Invest., 1945, 24, 316.

6. Gibson, J. G., 2nd, and Evelyn, K. A., Clinical studies of the blood volume. IV. Adaptation of the method to the photoelectric microcolorimeter. J. Clin. Invest., 1938, 17, 153.

7. Gregerson, M. I., A practical method for the determination of blood volume with the dye T-1824. A survey of the present basis of the dye-method and its clinical application. J. Lab. \& Clin. Med., 1944, 29, 1266.

8. Forbes, G. B., and Perley, A., Estimation of total body sodium by isotopic dilution. I. Studies on young adults. J. Clin. Invest., 1951, 30, 558.

9. Schloerb, P. R., Friis-Hansen, B. J., Edelman, I. S., Solomon, A. K., and Moore, F. D., The measurement of total body water in human subjects by deuterium oxide dilution. J. Clin. Invest., 1950, 29, 1296.

10. Schloerb, P. R., Friis-Hansen, B. J., Edelman, I. S., Sheldon, D. B., and Moore, F. D., The measurement of deuterium oxide in body fluids by the falling drop method. J. Lab. \& Clin. Med., 1951, 37, 653.
11. Hiller, A., Plazin, J., and Van Slyke, D. D., A study of conditions for Kjeldahl determination of nitrogen proteins. Description of methods with mercury as catalyst, and titrimetric and gasometric measurements of the ammonia formed. J. Biol. Chem., 1948, 176, 1401.

12. Howe, P. E., The use of sodium sulfate as the globulin precipitant in the determination of proteins in blood. J. Biol. Chem., 1921, 49, 93.

13. Levitt, M. F., and Gaudino, M., Measurement of body water compartments. Am. J. Med., 1950, 9, 208.

14. Edelman, I. S., Haley, H. B., Schloerb, P. R., Sheldon, D. B., Friis-Hansen, B. J., Stoll, G., and Moore, F. D., Further observations on total body water. I. Normal values throughout the life span. Surg., Gynec. \& Obst., 1952, 95, 1.

15. Pace, N., and Rathbun, E. N., Studies on body composition. III. The body water and chemically combined nitrogen content in relation to fat content. J. Biol. Chem., 1945, 158, 685.

16. Prentice, T. C., Siri, W., Berlin, N. I., Hyde, G. M., Parsons, R. J., Joiner, E. E., and Lawrence, J. H., Studies of total body water with tritium. J. Clin. Invest., 1952, 31, 412.

17. Eisenmenger, W. J., Ahrens, E. H., Jr., Blondheim, S. H., and Kunkel, H. G., The effect of rigid sodium restriction in patients with cirrhosis of the liver and ascites. J. Lab. \& Clin. Med., 1949, 34, 1029.

18. Edelman, I. S., Olney, J. M., James, A. H., Brooks, L., and Moore, F. D., Body composition: studies in the human being by the dilution principle. Science, 1952, 115, 447. 